ISSN 2709-9210

Journal of Service, Innovation and Sustainable Development

Vol. 2 (2021) No. 1, pp. 1-11

DOI:10.33168/SISD.2021.0101

\title{
Does ICT Affect the Financial Development? The Syrian Evidence
}

\author{
Ibrahim Alnafrah ${ }^{1}$, Rama Sultan ${ }^{1}$, Roua Aldoumani ${ }^{1}$, Sulaiman Mouselli ${ }^{2, *}$ \\ ${ }^{1}$ Faculty of Economics, Damascus University, Syria \\ 2,*Faculty of Business Administration, Arab International University, Syria \\ ${ }^{1}$ ibrahimnafrah@gmail.com; ${ }^{2}$ rama.sult1994@gmail.com; ${ }^{3}$ D1rouaa@gmail.com; \\ ${ }^{4, *}$ s-mousele@aiu.edu.sy
}

\begin{abstract}
The digital revolution affects all economic aspects and the financial sector is not an exception. Despite the wide evidence on the influence of Information, Communication, and Technology (ICT) on the financial sector advancement, this topic has yet to be researched in Syria. We explore the effect of five proxies of ICT on financial development using multiple regression model for the period 2005 to 2017 . We also conduct marginal effect analysis to identify the impact of penetration of mobile phones on the financial development with war and without it. We find that there is a significant positive influence of the number of mobile subscribers on the financial development index in Syria. Our result is consistent with Alshubiri et al. (2019) who find that a positive and significant impact exists of fixed broadband on financial development in GCC countries. However, the number of telephone subscribers has insignificant effect of the Syrian financial development. The war seems to have a significant adverse effect on the financial development in Syria. In addition, we find that the marginal influence of mobile subscription on the index of financial development without war is larger compared to the case with war. We conclude that digital transformation has great potentials for advancing the Syrian financial sector especially if accompanied with more investment in ICT infrastructure.
\end{abstract}

Keywords: ICT, financial development, marginal effect analysis, mobile subscription, Syria. 


\section{Introduction}

The financial sector, and its advancement, have an indisputable impact on macroeconomic indicators to the point that many developed countries attribute a large percentage of their economic development to this sector. In comparison to other industries, ICT has deeper and wider applications in the financial industry because it can considerably improves the operational efficiency of financial institutions (Cheng, Chien, and Lee, 2021). The combination of finance with technology, known as FinTech, reshapes the worldwide financial industry and has influential impact on all many other sectors.

The financial sector in Syria has long traditions that can be traced to the establishment of first bank in 1890. Until 1961, the number of functioning banks in Syria reached 21, 7 of them were foreign banks, and with the existence of trading rooms in Aleppo and Damascus to trade stocks. However, the nationalization wave that started with nationalising large private industrial and agricultural companies in 1961 followed by banks in 1963, undermined the development of financial sector as stocks become valueless and nationalized and restructured banks turned into six state banks.

The Syrian financial sector has witnessed a rapid development since 2001 with the issue of decree No.28 that permitted the establishment of private banks. It was not only their establishment that sparked a new hope for the financial sector, but also the requirement that they should take the legal form of corporations represented the cornerstone for the later establishment of Damascus Securities Exchange. Electronic banking services are generally offered by Syrian private banks but electronic payment system is yet to function.

There are many channels at which ICT advancement affect financial sector development. Regarding banks, ICT encourages the spread of e-banking (Szopinski, 2016; Takieddine and Sun, 2015) and more specifically mobile banking (Alalwan, Dwivedi, and Rana, 2017; Sharma, Govindaluri, Al-Muharrami, and Tarhini, 2017; Shaikh and Karjaluoto, 2015). Cronin (1997) argues that internet banking helps banks maintain direct relations with their customers and contribute towards developing additional customized services. Moreover, Nsouli and Schaechler (2002) argue that ICT encourages competition among banks because customers can easily compare banks' services and products. Furthermore, Raihan (2001) contends that ICT advancements enable foreign banks in Bangladesh increase information timeliness and accuracy, benefitting its customers, employees and management. In addition, Shamim (2007) suggests that advancements in ICT increases the operational efficiency of financial intermediation through improving the financial infrastructure of financial institutions and decreasing the marginal costs of financial intermediation.

Advancements in ICT are also pivotal for the development of financial markets and the stability of financial system. Allen et al. (2001) suggest that ICT enables broader and faster access to information and consequently reduces information 
asymmetry through lowering communication, computation and data processing costs. Moreover, Shamim (2007) argues that ICT increases stock market efficiency through extra price transparency, which will in turn attract more investors and increase stock market liquidity. That is, better connectivity significantly advances financial depth. More recently, Arner, Barberies and Buckley (2016) argue that the integration of ICT in the framework of financial regulation and oversight, called regtech, contributes towards increasing the quality of oversight and lowering the costs of compliance with regulatory requirements. As a result, regtech reduces the instability of the overall financial system (Arner, Barberies and Buckley (2018); Arner, Zetzsche, Buckley and Barberis (2017)) and enhances people's confidence in financial firms which should be reflected in more funds attracted to the formal financial system.

This article is organised as follow. Section 2 reviews the evidence of the impact of ICT on financial development. Section 3 illustrates the data used and methodology applied as well as the regression results. Section 4 presents conclusions and provides recommendations for financial institutions, policy makers and researchers.

\section{Literature Review}

The association between economic growth and financial development has been investigated intensively in the literature. Some studies have considered finance as the main contributor to economic growth (Goldsmith (1969); King and Levine (1993)). Levine and Zervos (1998) argue that the development of the banking sector was the cause of economic growth. On the contrary, Cheng, Chien, and Lee (2021) argue that financial development is unfavourable for economic growth but this undesirable impact is larger in high-income countries.

The evidence on the influence of ICT on economic growth is intensive. In the seminal review paper of $\mathrm{Vu}$, Hanafizadeh, Bohlin (2020), they conducted a thorough survey of scientific articles dealing with the relationship between ICT and economic growth. They conclude that global economic performance during the period from 1997 to 2017, at which the ICT advancement spread quickly among countries and companies, was significantly higher in comparison to the global economic performance during the previous ten years and expects ICT changes to increase faster in the coming decades. Koutroumpis (2009) investigates the influence of one variable of ICT (broadband) on economic growth in 22 OPEC countries. He documents a positive influence of broadband spread on economic growth. Vu (2011) examines the impact of ICT, as proxied by mobile phone users, internet users, and personal computers on economic growth. He shows that the influence of internet users on the growth of economy was greater than those of mobile phones, which in turn is greater than that of personal computers. Lee et al. (2012) illustrate that the expansion of mobile cellular users is an important contributor to economic growth in African subSaharan countries. Pradhan et al. (2018) examine the effect of ICT infrastructure (broadband and internet users) on economic growth for 20 countries. They find a 
general positive linkage between ICT infrastructure and economic growth. Portfoillo, Mogoll'on, Gonz'alez (2020) analyse the impact of ICT, proxied by digital performance and competitiveness index, on economic growth in the EU countries and confirm that ICT has a positive impact on economic growth.

The influence of ICT on financial development was investigated either directly or indirectly as mediator to assess its on other variables such as economic growth. Among the indirect studies, Shamim (2007) investigates the indirect linkage between the ICT level (represented by four variables focusing on the results from cell phone subscribers and users of internet) and economic growth through its effect on financial development. He shows that enhancing the number of cell phone subscribers and the number of users of internet significantly supports the financial depth, which in turn lead to higher economic growth. In a same vein, Pradhan et al (2015) investigate the association between ICT, financial development and economic growth in 21 Asian countries and conclude that these variables are cointegrated and both ICT and financial development contributes towards the long-term economic growth of the investigated countries. Asongu and Nwachukwu (2017) in their study, they assess the role of ICT (represented by cell phone and internet) in supplementing financial access as part of financial sector development. They show that the interaction between ICT and financial formalization reduces financial activity and vice versa. In addition, despite the negative impact of financial informalization, the aggregate net impact is positive. Sepehrdoust (2018) investigates the effect of ICT on financial development in the developing economics of OPEC countries for the period and find that an $1 \%$ increases in the financial development index and internet users improved economic growth by 0.048 and 0.050 percent respectively. Cheng, Chien, and Lee (2021) find that ICT reduces the negative effect of financial development on economic growth in rich countries.

Among the studies that investigate the direct effect of ICT on financial development is Alshubiri, Jamil and Elheddad (2019). They proxy for ICT by internet users, fixed broadband penetration, mobile subscribers, social media penetration, international band width per internet user) and conduct their study on six GCC countries. They find that one percent rise in fixed broadband causes $2 \%$ rise in financial development, and one percent increase in internet users results in $0.09 \%$ increase in financial development. In a similar study, Lechman and Marszk (2019) investigate the effect of ICT on various features of financial development in European countries. They find that the association between ICT and financial development is positive in general and also on selective aspects of it. Moreover, Del Gaudio, Porzio, Sampagnaro, and Verdoliva (2020) report a positive link between banks' profitability (ROA) and the implementation and diffusion of ICT, and that innovations in ICT enhance the banking industry performance especially with regard to the move from traditional payment services to digital payment system. In addition, they find that the ICT deployment increases the stability of banks at the country level as a whole, and 
the ICT spread and adoption has a significant positive effect on bank capitalization. Based on the above-mentioned review, we can formulate the study hypotheses as:

H1: ICT advancements increase financial development in Syria

$\mathrm{H} 2$ : The war negatively affect the financial development in Syria.

\section{Data and Methodology}

This article uses five independent variables: Mobile subscriptions per 100 inhabitants, fixed telephone subscriptions per 100 inhabitants, Internet users, fixed broadband subscriptions per 100 inhabitants, and dummy variable as a proxy of the war that began in 2011, and one dependent variable, that is financial development index. The dataset used in this study spans 13 years from 2005 to 2017. The short period covered in this study is due the scarcity of data about financial system activities in Syria. We present a summary of descriptive statistics for the investigated variables in Table 1.

Table 1: Descriptive statistics

\begin{tabular}{|c|c|c|c|c|c|c|}
\hline & FD & Mobile & Internet & Telephone & Broadband & War \\
\hline Mean & 0.133386 & 55.12826 & 21.09028 & 18.74654 & 2.147111 & 0.538462 \\
\hline Median & 0.131572 & 61.27082 & 22.50000 & 19.04756 & 1.185826 & 1.000000 \\
\hline Maximum & 0.154594 & 89.99936 & 34.25340 & 22.62064 & 6.321387 & 1.000000 \\
\hline Minimum & 0.106780 & 16.06651 & 5.648106 & 15.81129 & 0.027587 & 0.000000 \\
\hline Std. Dev. & 0.012239 & 23.01639 & 9.250556 & 1.986198 & 2.362405 & 0.518875 \\
\hline Skewness & -0.310295 & -0.253550 & -0.280245 & 0.184739 & 0.693952 & -0.154303 \\
\hline Kurtosis & 3.207366 & 1.906687 & 1.872825 & 2.335131 & 1.889199 & 1.023810 \\
\hline Jarque-Bera & 0.231905 & 0.786761 & 0.858365 & 0.313389 & 1.711752 & 2.166974 \\
\hline Probability & 0.890518 & 0.674772 & 0.651041 & 0.854965 & 0.424911 & 0.338413 \\
\hline Shapiro-Wilk & 0.95296 & 0.956 & 0.95747 & 0.97187 & 0.82658 & 0.6457 \\
\hline Probability & 0.6438 & 0.6975 & 0.7143 & 0.9156 & $0.01435^{* *}$ & $0.0001673^{* * * *}$ \\
\hline Sum & 1.734021 & 716.6674 & 274.1736 & 243.7050 & 27.91244 & 7.000000 \\
\hline Sum Sq. Dev. & 0.001798 & 6357.050 & 1026.873 & 47.33978 & 66.97151 & 3.230769 \\
\hline Observations & 13 & 13 & 13 & 13 & 13 & 13 \\
\hline
\end{tabular}

$* * *, * *, *$ indicate significance at the 1,5 , and $10 \%$ level of significance, respectively.

Since we have less than 30 observations, we need to check the normality distribution of all studied variables. The results of Shapiro-Wilk and Jarque-Bera test show that all variables are normally distributed, except broadband and war variables. Therefore, the broadband variable was excluded from the analysis. Regarding the war variable, we did not exclude it from the analysis since its distribution is originally binary.

The initial pool of variables included several ICT related variables such as internet users, and broadband subscribers. After conducting a stepwise regression, we omitted those variables that reduce the quality of the model and kept both mobile and telephone subscribers. Table 3 shows the results of running the following formula, 


$$
F D_{t}=C+\beta_{1} \text { Mobile }_{t}+\beta_{2} \text { Telephone }_{t}+\beta_{3} W A R_{t}+\mathrm{e}_{\mathrm{t}}
$$

Table 2: Multiple regression model results

\begin{tabular}{|c|c|c|c|c|}
\hline Variable & Coefficient & Std. Error & t-Statistic & Prob. \\
\hline MOBILE & 0.000708 & 0.000230 & 3.080948 & $0.013^{* *}$ \\
\hline TELEPHONE & 0.002852 & 0.001719 & 1.659293 & 0.1314 \\
\hline WAR & -0.037304 & 0.011364 & -3.282790 & $0.0095^{* * *}$ \\
\hline C & 0.061000 & 0.032509 & 1.876393 & $0.0933^{*}$ \\
\hline R-squared & \multicolumn{5}{|c|}{0.561081} \\
\hline Adjusted R-squared & \multicolumn{5}{|c|}{0.414775} \\
\hline F-statistic & \multicolumn{5}{|c|}{0.05085960} \\
\hline Prob(F-statistic) & \multicolumn{5}{|c|}{} \\
\hline
\end{tabular}

***, **, * indicate significance at the 1, 5, and 10\% level of significance, respectively.

The results from the multiple regression model show that there is a significant positive impact for the number of mobile subscribers on the financial development index in Syria, which confirms our first hypothesis. However, the results indicate that there is insignificant relationship between the number of telephone subscribers and the financial development. These results imply the crucial role of mobile phones in financial development in low-income countries such as Syria, where any new digital payment system can be easily implemented and disseminated among citizens. Despite the role of fixed telephone infrastructure in facilitating setting up the IDSL network in the country, the telephone itself has become an instrument to get access to the broadband services. In other words, people in Syria buy fixed telephones to get cheaper and faster access to Internet, not to use it in daily communications. Therefore, it is logical to find that the fixed telephone does not have a significant relationship with the financial development index. It can be said that the fixed telephone play indirect role in the financial development in Syria.

The results also indicate that the impact of the war on the financial development in Syria is significantly negative reflecting the negative impact of the war on the financial development in Syria in confirmation of our second hypothesis.

To detect the impact of penetration of mobile phones on the financial development with and without the war, we conducted a marginal effect analysis. The results of the marginal effect analysis are represented in Fig. 1.

Results in Fig. 1 shows that the marginal impact of mobile subscription on the index of financial development in the case of war is less than its effect without war by four points. It worth mentioning here, that these four points toke more than decade for Syrian financial system gain. This illustrates the significant impact of the war on the financial system-related activities. 
To elaborate in more depth the marginal effect of the mobile subscriptions on the financial development index, we adjusted the previous analysis by taking the level of telephone penetration into account. The results of the adjusted marginal impact of mobile subscription on the financial development are represented in Fig. 2.

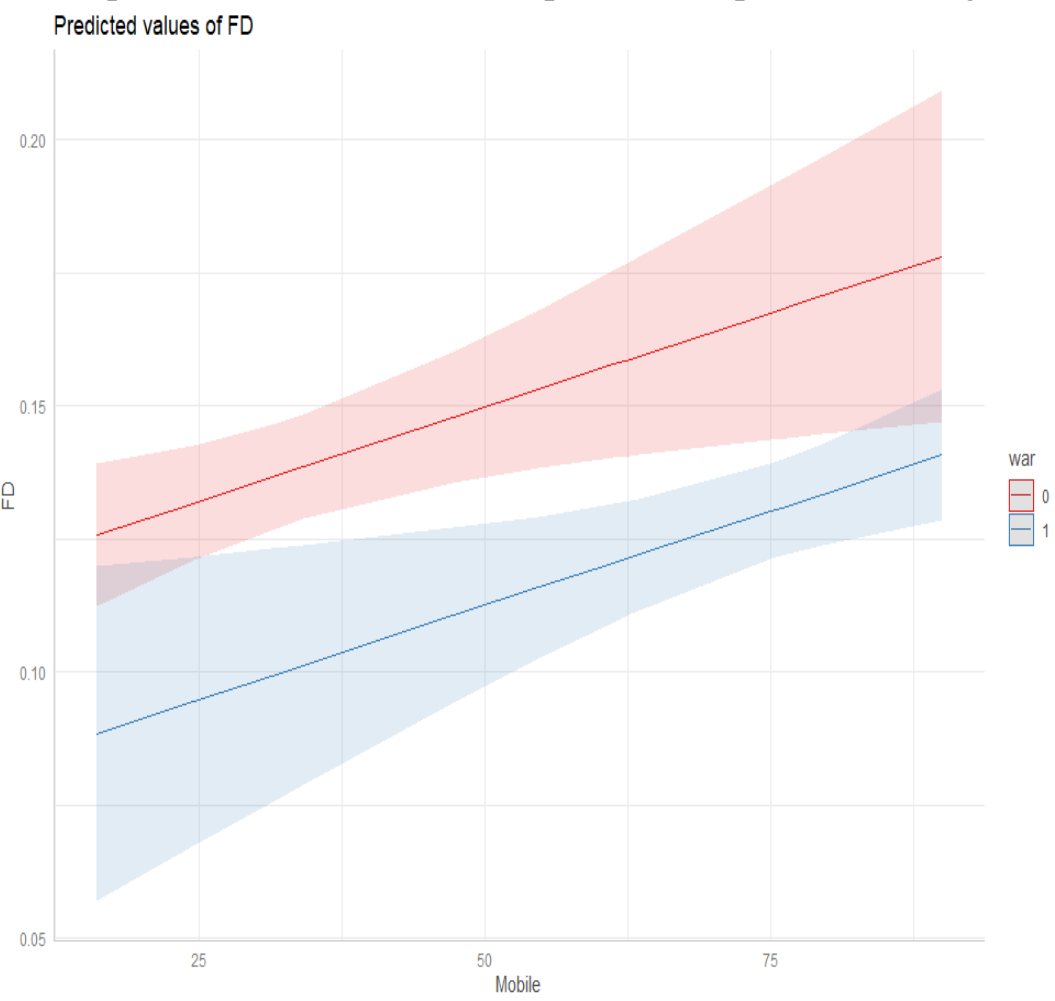

Fig. 1: Marginal impact of mobile subscription on Syrian financial development

Fig. 2 shows that the marginal impact of mobile subscription on the index of financial development in the case of war is less than its effect without war by three points. This resluts are assumed to be combined with high levels of telephone penetration. On the other hand, when assuming a low level of telephone penetration, the marginal effect of mobile subscription on the financial development index in the case of war was less than its effect without war by four points. This implies that the telephone penetration effect on the financial development index is not that significant in both cases, with and without war.

\section{Conclusions and Recommendations}

We investigate the effect of ICT on financial development in Syria using multiple regression model for the period 2005 to 2017. We also conduct marginal effect analysis to identify the impact of penetration of mobile phones on the financial development with war and without it. Our results suggest that there is a positive and 
significant effect of the number of mobile subscribers on the financial development index in Syria. This result is consistent with Lechman and Marszk (2019) findings of a positive impact of ICT on financial devlopment. Furthemore, our results are consistent with Alshubiri et al. (2019) who find that a rise in fixed broadband subscription has a significantly positive impact on financial development in GCC countries. However, the number of telephone subscribers has insignificant influence on the Syrian financial development. The war seems to have a significant negative effect on the financial development in Syria. In addition, we find that the marginal impact of mobile subscription on the index of financial development without war is larger compared to the case with war. We conclude that digital transformation has great potentials for advancing the Syrian financial sector especially if accompanied with more investment in ICT infrastructure.

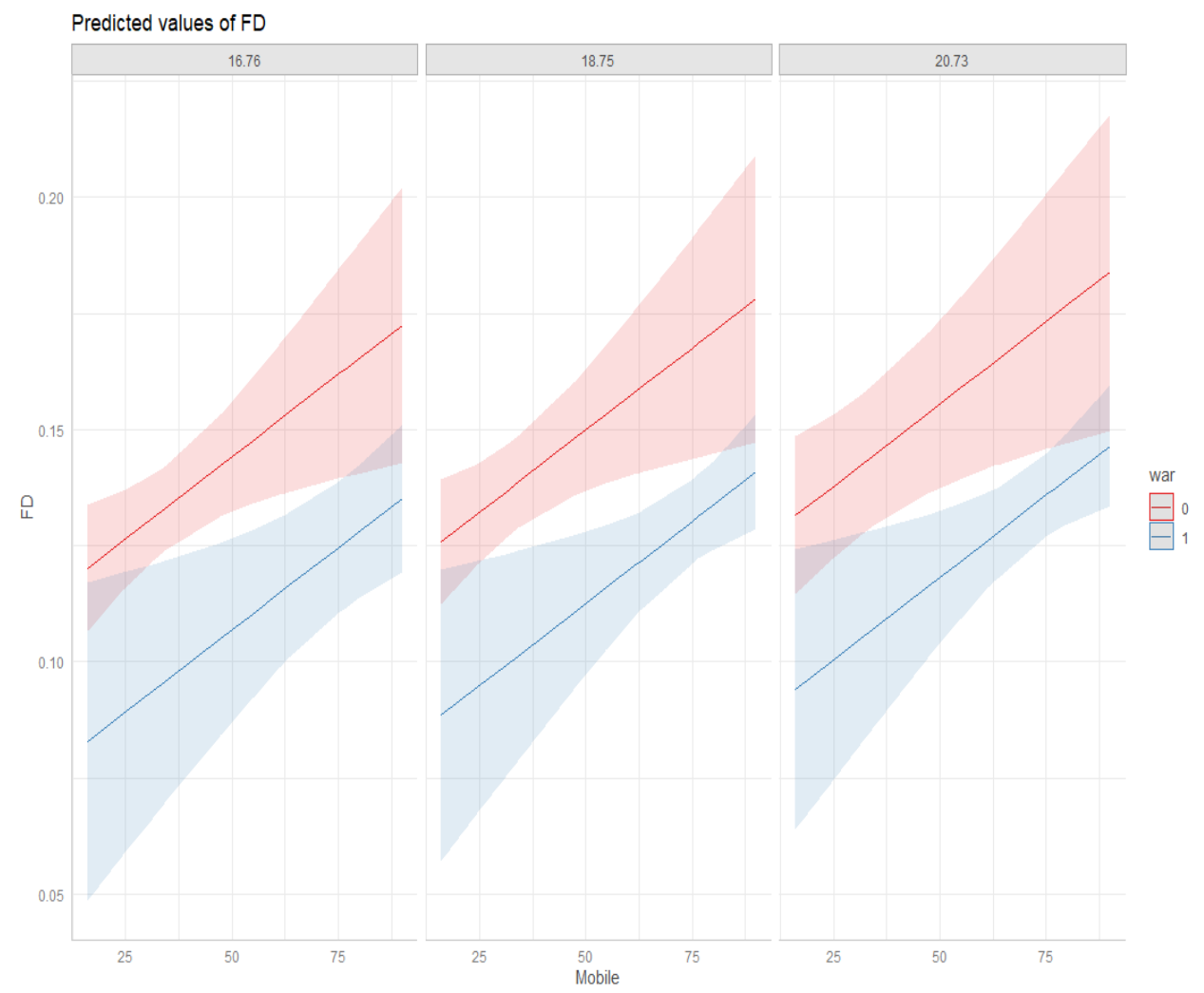

Fig. 2: Adjusted marginal impact of mobile subscription on the Syrian financial development.

Our recommendations are fourfold. First, Syrian financial institutions should enhance their financial infrastructure to capitalise on the opportunities that emerge with Fintech. Second, supervisory and oversight authorities may take advantage of innovative ICT applications to increase stock market efficiency and people's trust in 
the stability of the financial system. Third, the Ministry of Telecommunication and Technology should rethink methods to improve the mobile service, speed and coverage, or establish a independent Asymmetric Digital Subscriber Line (ADSL) network seprate from the fixed telephone network as this will contribute towards developed financial sector as an increase in electronic banking and electronic payments cannot be seen without high quality telecommunication infrastructure. Fourth, researchers may investigate the effect of ICT development on individual indicators from the financial sector such as banks, insurance, and stock market development.

\section{References}

Alalwan, A. A., Dwivedi, Y. K., \& Rana, N. P. (2017). Factors influencing adoption of mobile banking by Jordanian bank customers: Extending UTAUT2 with trust. International Journal of Information Management, 37(3), 99-110.

Allen, F., McAndrews, J. and Strahan, P. (2001), "E-finance: an introduction", working paper, Financial Institutions Center, The Wharton School, University of Pennsylvania, Philadelphia, PA, available at: www.finirs.org/papers/02/0210.pdf.

Alshubiri Faris, Syed Ahsan Jamil and Mohamed Elheddad. (2019). The impact of ICT on financial development: Empirical evidence from the Gulf Cooperation Council countries. International Journal of Engineering Business Management.

Antonio Fern'andez-Portillo, Manuel Almod’ovar-Gonz'alez, Ricardo Hern'andezMogoll'on. (2020).

Impact of ICT development on economic growth. A study of OECD European union countries. Telecommunications Policy 63(2020).

Arner, D. W., Barberis, J., \& Buckley, R. P. (2016). The emergence of RegTech 2.0: From know your customer to know your data. Journal of Financial Transformation, 44, 79-86.

Arner, D. W., Barberis, J., \& Buckley, R. P. (2018). RegTech: Building a Better Financial System. In Vol.1. Handbook of blockchain, digital finance, and inclusion. (pp. 359-373): Academic Press.

Arner, D. W., Zetzsche, D. A., Buckley, R. P., \& Barberis, J. N. (2017). FinTech and Reg-Tech: Enabling innovation while preserving financial stability. Georgetown Journal of International Affairs, 18(3), 47-58. 
Belinda L. Del Gaudio, Claudio Porzio, Gabriele Sampagnaro, Vincenzo Verdoliva. (2020). How do mobile, internet and ICT diffusion affect the banking industry? An empirical analysis. European Management Journal.

Cheng, C. Y., Chien, M. S., \& Lee, C. C. (2021). ICT diffusion, financial development, and economic growth: An international cross-country analysis. Economic modelling, 94, 662-671.

Cronin, M.J. (1997), Banking and Finance on the Internet, Wiley Publishers, New York, NY Nsouli, S.M. and Schaechter, S. (2002), "Challenges of the e-banking revolution", Finance and Development, 39(3).

Hamid S. (2018). Impact of information and communication technology and financial development on economic growth of OPEC developing economies. Kasetsart Journal of Social Sciences.

Lechman E., Marszk A. (2019). ICT-Driven Economic and Financial Development, 193-271.

Goldsmith, R. W. (1969). Financial structure and development. New Haven, CT: Yale University Press.

King, R. G., \& Levine, R. (1993). Finance, entrepreneurship, and growth: Theory and evidence. The Journal of Monetary Economics.

Levine, R., \& Zervos, S. (1998). Capital control liberalization and stock market development. World Development.

Pantelis K.. (2009). the economic impact of broadband on growth: A simultaneous approach. Telecommunications Policy.

Pradhan, Rudra P., Mak B. Arvin, and Neville R. Norman. (2015). The dynamics of information and communications technologies infrastructure, economic growth, and financial development: Evidence from Asian countries. Technology in Society.

Pradhan, Rudra P., Mallik Girijasankar, and Tapan P. Bagchi. (2018). Information communication technology (ICT) infrastructure and economic growth: A causality evinced by cross-country panel data. IIMB Management Review.

Raihan, A. (2001), The state of e-finance in developing countries: Bangladesh perspective, paper presented in Expert Group Meeting on Improving Competitiveness 
of SMEs in Developing Countries: Role of Finance, Including E-finance to Enhance Enterprise Development, Geneva.

Shaikh, A. A., \& Karjaluoto, H. (2015). Mobile banking adoption: A literature review. Telematics and Informatics, 32(1), 129-142.

Shamim F. (2007) The ICT environment, financia sector and economic growth: a cross-country analysis. Journal of Economic Studies.

Sharma, S. K., Govindaluri, S. M., Al-Muharrami, S., \& Tarhini, A. (2017). A multianalytical model for mobile banking adoption: A developing country perspective. Review of International Business and Strategy, 27(1), 133-148.

Simplice A. Asongu \& Jacinta C. Nwachukwu. (2017). ICT, Financial Sector Development and Financial Access. African Governance and Development Institute.

Szopi_nski, T. S. (2016). Factors affecting the adoption of online banking in Poland. Journal of Business Research, 69(11), 4763-4768.

Pradhan, Rudra P., Mallik Girijasankar, and Tapan P. Bagchi. (2018). Information communication technology (ICT) infrastructure and economic growth: A causality evinced by cross-country panel data. IIMB Management Review.

Takieddine, S., \& Sun, J. (2015). Internet banking diffusion: A country-level analysis. Electronic Commerce Research and Applications, 14(5), 361-371.

Vu K., Hanafizadeh P., Bohlin E. (2020). ICT as a driver of economic growth: A survey of the literature and directions for future research. Telecommunications Policy, 44(2020).

Vu, Khuong M. (2011). ICT as a source of economic growth in the information age: Empirical evidence from the 1996-2005 period. Telecommunications Policy. 